\section{Pendidikan Karakter Islami. Karakter Utuel Albab Di Dalam Al-Ouran}

Pendidikan karakter Islami ini merupakan salah satu alternatif solusi dalam menghadapi globalisasi dan modernisasi saat ini, Globalisasi dan modernisasi telah mengubah cara atau gaya hidup masyarakat saat ini yang cenderung konsumtif, hedonis, dan materialis.. Pendidikan karakter Islami yang ditulis dalam buku ini menjelaskan sumbernya yang tidak hanya dari nalar ataupun moral šocial, Lebih dari itu, pendidikan karakter Islami menawarkan sebuah konsep yang lebih komprehensif yang bersumber dari logika, etika, estetika, teologi dan syariat. Nilai teologi dan syariat inilah yang menjadi kekhasan pendidikan karakter Islami. Pengembangan karakter Islami tidak hanya mengukur aspek salah dan benar, baik dan buruk, indah dan jelek, tetapi juga tauhid dan syirik atau halal dan haram.

Kajian pendidikan karakter Islami dalam buku ini juga bersumber langsung dari ayat al-Quran, terutama berkaitan dengan karakter ulul albab. Karakter ulul albab digambarkan secara detail oleh buku ini. Penulis mengambil sumbernya langsung dari al-Quran melalui penafsiran para ulama, yaitu Wahbah al-Zuhayli dan M. Quraish Shihab. Keduanya samasama memaknai ulul albab sebagai sosok yang istimewa di mata Allah. Mereka mempunyai keistemewaan yang sudah dipaparkan dalam beberapa ayat al-Quran, yaitu ulul albab sebagau sosok yang mempunyai akal yang murni dan sehat, sehingga bisa mengambil pelajaran dari ayatayat al-Quran, mampu menyeimbangkan antara kemampuan zikir dan piker, dan sosok yang mendapatkan hidayah dan hikmah dari Allah.
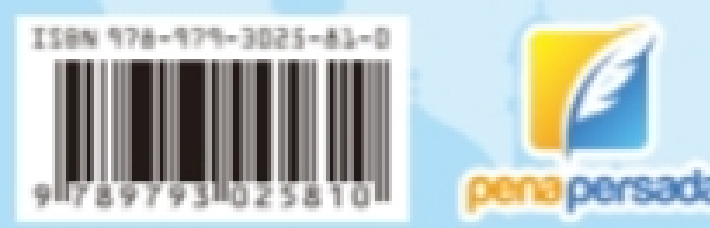

Dr. Nur Chanifah, S.Pd.I, M.Pd.I

Abu Samsudin, S.Th.I, M.Th.I

\section{Pendidikan} Karakter Islami: Karakter Utul Albab Di Dalam Al-Ouran

Pengantar: Prof. Dr. Thohit Luth, MA

(Guru Besar Universitas Brawijaya)

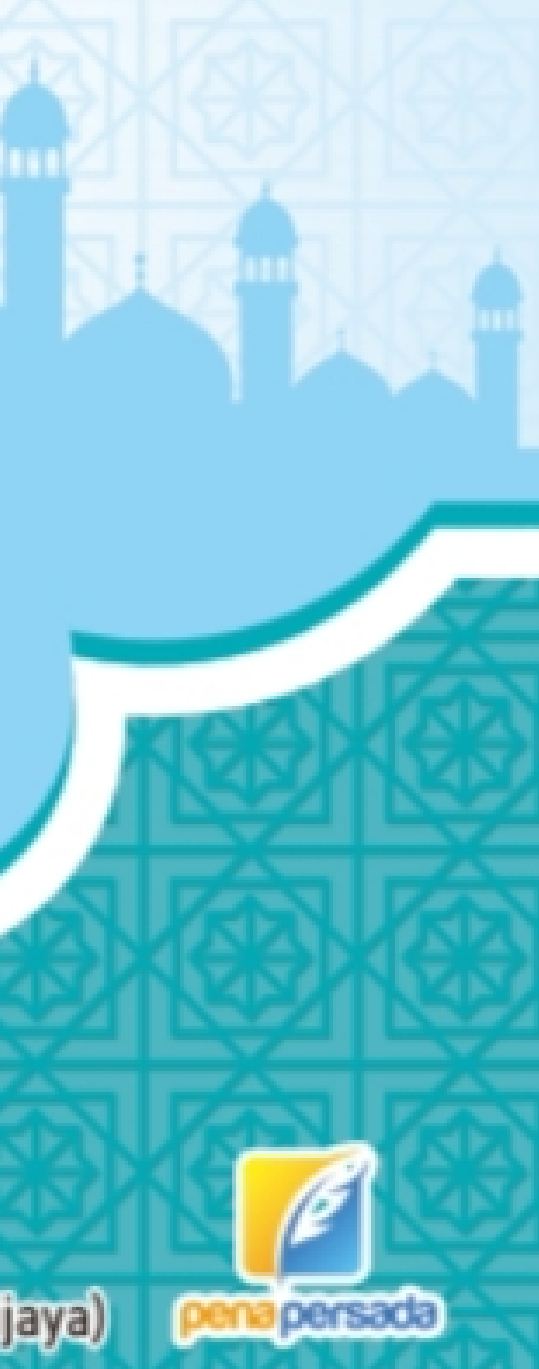




\title{
PENDIDIKAN KARAKTER ISLAMI: KARAKTER ULUL ALBAB DI DALAM AL-QUR'AN
}

\author{
Pengantar : \\ Prof. Dr. Thohir Luth, MA \\ (Guru Besar Universitas Brawijaya) \\ Dr. Nur Chanifah, S.Pd.I, M.Pd.I \\ Abu Samsudin, S, Th.I, M.Th.I
}

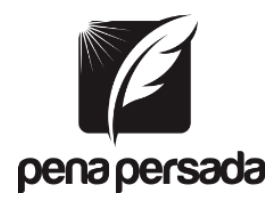

PENERBIT CV. PENA PERSADA 


\title{
PENDIDIKAN KARAKTER ISLAMI: \\ KARAKTER ULUL ALBAB DI DALAM AL-QUR'AN
}

\author{
Penulis : \\ Dr. Nur Chanifah, S.Pd.I, M.Pd.I \\ Abu Samsudin, S, Th.I, M.Th.I \\ ISBN : 978-979-3025-81-0 \\ Desain Sampul \\ Retnani Nur Briliant \\ Penata Letak \\ Fajar T. Septiono \\ Penerbit CV. Pena Persada \\ Redaksi : \\ Jl. Gerilya No.292 Purwokerto Selatan, Kab. Banyumas \\ Jawa Tengah \\ Email : penerbit.penapersada@gmail.com \\ Website : www.penapersada.com \\ Phone : 0857-2604-2979
}

\section{Anggota IKAPI}

All right reserved

Cetakan Pertama : 2019

Hak Cipta dilindungi oleh undang-undang.

Dilarang memperbanyak karya tulis ini dalam bentuk dan cara apapun tanpa izin dari penerbit. 


\section{PENGANTAR PAKAR}

Buku pendidikan karakter Islami ini merupakan salah satu buku penting dan cocok untuk menghadapi globalisasi dan modernisasi saat ini. Globalisasi dan modernisasi telah mengubah cara atau gaya hidup masyarakat saat ini yang cenderung konsumtif, hedonis, dan materialis. Tidak hanya itu saja, banyak masalah yang muncul seperti krisis moral dan tingkat kriminalitas yang semakin merajalela. Untuk itu, perlu kita kembalikan ruh pendidikan kita sebagai salah satu elemen penting dalam mendidik dan mencerdaskan bangsa agar berakhlak mulia.

Pendidikan karakter Islami ini merupakan salah satu alternatif solusinya. Pendidikan karakter Islami yang ditulis dalam buku ini menjelaskan bagaimana karakter yang harus dikembangkan untuk generasi kita saat ini. Pendidikan karakter yang tidak hanya bersumber dari nalar ataupun moral social. Lebih dari itu, pendidikan karakter Islami menawarkan sebuah konsep yang lebih komprehensif yang bersumber dari logika, etika, estetika, teologi dan syariat. Nilai teologi dan syariat inilah yang menjadi kekhasan pendidikan karakter Islami.

Pengembangan karakternya tidak hanya mengukur aspek salah dan benar, baik dan buruk, indah dan jelek, tetapi juga tauhid dan syirik atau halal dan haram. Namun demikian, sumber utama dari pendidikan karakter Islami adalah al-Quran dan hadis. Keduanya bisa dijadikan sebagai standar dalam mengembangkan karakter Islami. Oleh karena itu, buku ini bagus untuk dijadikan referensi, karena kajian pendidikan karakter Islami langsung dari ayat al-Quran, terutama berkaitan dengan karakter ulul albab.

Karakter ulul albab digambarkan secara detail oleh buku ini. Penulis mengambil sumbernya langsung dari Al-Quran 
melalui penafsiran para ulama, yaitu Wahbah al-Zuhayli dan M. Quraish Shihab. Penulis juga mampu mengabstrakkan penafsiran tersebut dengan beberapa indikator dari karakter ulul albab tersebut.

Semoga buku yang ditulis oleh Dr. Nur Chanifah, M.Pd.I dan Abu Samsudin, S.Th.I, M.Th.I memberikan manfaat dan kontribusi dalam khazanah keilmuan di negeri ini, mampu melengkapi referensi-referensi lainnya, dan mampu memberikan solusi permasalahan bangsa ini yang tengah menghadapi krisis moral.

Malang, Januari 2019

Prof. Dr. Thohir Luth, MA 


\section{PENGANTAR PENULIS}

Alhamdulillah puji syukur kami panjatkan kepada Allah Swt atas segala limpahan rahmat dan karuniaNya sehingga penulis dapat menyelesaikan penulisan buku ini dengan judul Pendidikan Karakter Islami: Karakter Ulul Albab dalam al-Quran.

Shalawat dan salam semoga senantiasa terlimpah kepada baginda Rasulullah Muhammad Saw yang telah membimbing kita ke jalan yang benar dengan Islam. Semoga kelak di hari kiamat kita diakui sebagai umat beliau dan mendapatkan syafa'atnya.

Buku ini merupakan hasil karya dari kami berdua (suami istri) yang mencakup beberapa hasil karya penulis sebelumnya, baik berupa disertasi (sebagian naskah), tesis, artikel ilmiah, maupun makalah. Dari beberapa tulisan tersebut, kami sempurnakan sehingga bisa menjadi buku referensi yang lebih komprehensif dan layak untuk dibukukan.

Penulisan buku ini dilatarbelakangi dari minimnya referensi tentang pendidikan karakter Islami, terutama dalam kaitannya dengan karakter ulul albab. Buku-buku pendidikan karakter Islam yang sudah beredar di masyarakat lebih banyak mengkaji bagaimana pendidikan karakter dalam perspektif Islam, bukan konsep pendidikan karakter Islami yang sumber utamanya dari al-Quran dan Hadis dan sumber lainnya seperti logika, etika, estetika, teologi dan syari'at. Inilah yang membedakan pendidikan karakter yang dikembangkan di barat dengan yang ada di dalam Islam. Pendidikan karakter Islami harus memperhatikan nilai-nilai Islam baik yang ada di dalam alQuran maupun hadis (syariat) dan teologi, bukan value free atau hanya berdasarkan logika dan norma sosial saja.

Selanjutnya fokus pembahasan nilai karakter dalam buku ini adalah karakter ulul albab yang ada di dalam al-Quran. 
Dengan metote Maudhu'i, penulis menelusuri ayat-ayat alAQuran yang berkaitan dengan ulul albab yang disebutkan di dalam al-Quran sebanyak 16 kali. Lebih lanjut, untuk mengkaji penasfirannya lebih mendalam, penulis lebih focus kepada penafsiran Wahbah Zuhayli dalam kitab tafsir al-Munir dan M. Quraish Shihab dalam kitab tafsirnya al-Misbah. Pemilihan tersebut didasarkan pada kredibilitas kedua mufassir tersebut yang merupakan mufassir kontemporer saat ini sehingga penafsirannya lebih cocok untuk kondisi saat ini. Pembahasan kedua kitab tafsir tersebut juga lebih komprehensif dari kitab tafsir yang lain.

Buku ini diawali dengan pembahasan tentang urgensi dan konsep pendidikan karakter secara umum kemudia baru dijelaskan konsep pendidikan karakter Islami. Konsep pendidikan karakter Islami diambil dari al-Quran dan hadis, serta beberapa ilmuwan muslim. Selanjutnya dibahas tentang nilai karakter yang dikembangkan, yaitu ulul al-albab dengan mengkaji biografi dan penafsiran dari Wahbah Zuhayli dan M. Quraish Shihab. Pembahasan terakhir tentang indikator karakter ulul albab dari kedua tafsir tersebut serta bagaimana persamaan dan perbedaan penafsirannya.

Selanjutnya penulisan buku ini tidak terlepas dari bantuan berbagai pihak baik yang berupa saran, masukan, inspirasi maupun bentuk lainnya. Untuk itu, secara khusus kami ucapkan terima kasih banyak kepada Prof. Dr. Tobroni, M.Si dan Dr. Agus Maimun selaku promotor disertasi kami yang sudah banyak memberikan kritik, saran, dan masukan. Bapak Dr. Sumarkhan, M.Ag selaku pembimbing tesis yang juga sudah banyak meluangkan waktu untuk membimbing penulis. Dan kepada semua pihak yang sudah membantu terselesaikannya penulisan buku ini. 
Buku ini kami persembahkan kepada keluarga kami, teruatama orang tua kami bapak Ahmad Rusydi, Ibu Sayyidatul Mas'adah, ibu almarhumah Fauzur Rohillah bapak badrudin dan ibu almarhumah Sudjinah serta nenek kami ibu Muzayyanah yang senantiasa mendoakan, memotivasi, dan mendidik kami. Kedua putri kami Bilqis Az-Zahro (lahir 2009) dan Aqilah adzka azkiya' el-Nawwara (lahir 2013) semoga bisa menjadi anak Sholihah yang bermanfaat bagi agama, bangsa dan negara. Semoga buku ini juga bisa menjadi motivasi dan jariyah bagi mereka semuanya. Amin ya rabbal 'alamin.

Penulis juga menyadari bahwa buku ini masih jauh dari sempurna. Oleh karena itu, penulis memohon maaf yang sebesarbesarnya atas kekurangan dan kesalahan yang ada pada buku ini. Penulis berharap semoga buku ini dapat bermanfaat bagi para pembaca umumnya dan khususnya bagi penulis sendiri.

Malang, Januari 2019

Penulis 


\section{DAFTAR ISI}

PENGANTAR PAKAR .......................................................... ii

PENGANTAR PENULIS .............................................................. $\mathrm{v}$

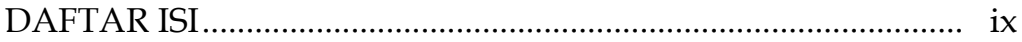

DAFTAR GAMBAR .......................................................... xii

DAFTAR TABEL ...................................................................... xiii

BAB I

PENDAHULUAN ….................................................. 1

A. Latar Belakang .................................................................. 2

B. Urgensi Kajian Karakter Ulul Albab dalam al-Quran ...... 9

BAB II

PENDIDIKAN KARAKTER .................................................. 16

A. Makna Karakter ….......................................................... 16

B. Paradigma Pendidikan Karakter ....................................... 23

C. Pendekatan Pendidikan Karakter ...................................... 23

D. Fungsi dan Tujuan Pendidikan Karakter .......................... 24

E. Landasan Yuridis Pendidikan Karakter ............................. 26

F. Strategi Pendidikan Karakter............................................ 29

BAB III

PENDIDIKAN KARAKTER ISLAMI ......................................... 40

A. Pendidikan Karakter dalam Perspektif Islam................... 40

B. Karakter Islami.............................................................. 44

C. Pendidikan Karakter menurut Ilmuwan Muslim ............. 48

D. Sumber Pendidikan Karakter Islami ................................... 55

BAB IV

PERAN KELUARGA DALAM PENDIDIKAN KARAKTER ..... 66

A. Urgensi Pendidikan Karakter dalam Keluarga ................. 66

B. Keluarga sebagai pilar utama pembentukan karakter ..... 69

C. Metode Pembentukan karakter anak usia dini dalam

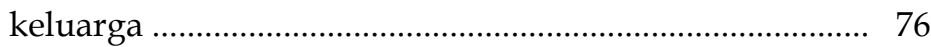


BAB V

KARAKTER ULUL ALBAB DALAM AL-QURAN ................... 84

A. Manusia dalam al-Quran ..................................................... 84

B. Manusia Ideal Menurut Islam ............................................. 90

C. Konsep Ulul albab dalam al-Quran................................... 94

D. Ulul albab dalam berbagai maknanya .............................. 96 BAB VI

WAHBAH AL-ZUHAILY DAN KARAKTERISTIK TAFSIR AL-MUNIR …...................................................................... 100

A. Biografi Wahbah al-Zuhaily ............................................. 100

B. Tafsir al-Munir ................................................................... 105

BAB VII

M. QURAISH SHIHAB DAN KARAKTERISTIK TAFSIR AL-MISBAH........................................................................... 111

A. Biografi M. Quraish Shihab .......................................... 111

B. Tafsir al-Misbah ........................................................... 116

BAB VIII

ULUL ALBAB DALAM TAFSIR AL-MUNIR DAN TAFSIR

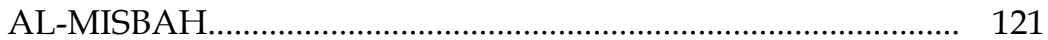

A. Tafsir Ayat ........................................................................... 121

B. Tipe Manusia Ideal (ulul albab) Menurut Wahbah Zuhaily dan M. Quraish Shihab...................................... 154

C. Persamaan dan Perbedaan Penafsiran .............................. 157

DAFTAR PUSTAKA ............................................................. 159

BIOGRAFI PENULIS ............................................................. 162 


\section{DAFTAR GAMBAR}

Gambar 1: Pendidikan Karakter Islami ........................................ 64

Gambar 2: Fungsi Keluarga dalam Membentuk Karakter Anak 71

x | Pendidikan Karakter Islami 


\section{DAFTAR TABEL}

Tabel 1: Inpres Nomor 1 tahun 2010 .......................................... 28

Tabel 2: Jenis karakter yang dikembangkan dalam sains........... 58 


\section{PENDIDIKAN KARAKTER ISLAMI:}

Karakter Ulul Albab di dalam Al-Qur'an 


\section{BAB I \\ PENDAHULUAN}

\section{A. Latar Belakang}

Pembangunan karakter di Indonesia merupakan perwujudan amanat Pancasila dan Pembukaan UUD 1945 yang dilatarbelakangi oleh realita permasalahan kebangsaan yang berkembang saat ini. Misalnya, bergesernya nilai etika dalam kehidupan berbangsa dan bernegara; memudarnya kesadaran terhadap nilai-nilai budaya bangsa; ancaman disintegrasi bangsa; dan melemahnya kemandirian bangsa. Untuk itu, Pemerintah menjadikan pembangunan karakter sebagai salah satu program prioritas pembangunan nasional. Semangat itu secara implisit ditegaskan dalam Rencana Pembangunan Jangka Panjang Nasional (RPJPN) tahun 20052015, di mana pendidikan karakter ditempatkan sebagai landasan untuk mewujudkan visi pembangunan nasional, yaitu mewujudkan masyarakat berakhlak mulia, bermoral, beretika, berbudaya, dan beradab berdasarkan falsafah Pancasila. ${ }^{1}$

Untuk mengimplementasikannya, maka pendidikan mempunyai peran yang sangat signifikan. Hal ini bisa dirujuk dari Undang-undang Nomor 20 Tahun 2003 tentang Sisdiknas pasal $3,^{2}$ bahwa hakikat pendidikan tidak hanya mengajar

\footnotetext{
${ }^{1}$ Hidayat Ma'ruf, Pendidikan Karakter di Perguruan Tinggi (Tinjauan Filosofis dan Metodologis), hal. 2

${ }^{2}$ Undang-undang tersebut menyatakan bahwa: "Pendidikan Nasional berfungsi mengembangkan kemampuan dan membentuk watak serta peradaban bangsa yang bermartabat dalam rangka mencerdaskan kehidupan bangsa, bertujuan untuk berkembangnya potensi peserta didik agar menjadi manusia yang beriman dan bertaqwa kepada Tuhan YME, berakhlak mulia, sehat, berilmu, cakap, kreatif, mandiri, dan menjadi warga yang demokratis serta bertanggung jawab.
} 
(transfer of knowledge) saja, tetapi lebih dari itu yaitu mendidik agar berakhlak. ${ }^{3}$ Menurut Furqan (2010), pengertian akhlak itu sama dengan karakter. Karakter merupakan kualitas mental atau kekuatan moral, akhlak, atau budi pekerti yang melekat pada diri seseorang sehingga mampu menjadi pendorong atau penggerak dalam melakukan sesuatu. ${ }^{4}$ Dengan demikian, tujuan dari pendidikan harus mengarah pada pembentukan akhlak atau karakter. Karakter yang terbangun diharapkan akan mendorong setiap manusia untuk mengerjakan sesuatu sesuai dengan suara hatinya. Karena suara hati tidak akan mengarah pada hal yang negatif.

Karakter atau akhlak juga merupakan landasan bagi bangsa untuk bangkit meraih kejayaannya. Jika akhlak tersebut hilang, maka hancurlah bangsa. Sebagaimana dijelaskan dalam al-Quran surat al-A'raf ayat 96:

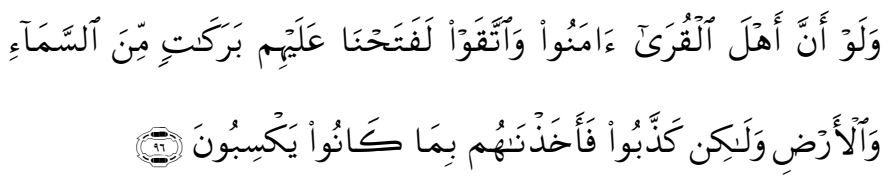

${ }^{3}$ Hal senada juga diungkapkan oleh Baidhawi dalam said Ismail Ali bahwa pendidikan itu bertujuan untuk memperbaiki akhlak atau lebih dikenal dengan istilah $t a^{\prime} d i b$. Lihat Said Ismail Ali. 2007. Usul al-Tarbiyah al-Islamiyah, (Kairo: Dar As-Salam), hal. 11-12. Pendapat tersebut juga didukung oleh M. Athiyah al-Abrasyi, menurutnya tujuan pendidikan Islam tujuan yang telah ditetapkan oleh Nabi Muhammad Saw sewaktu hidupnya, yaitu pembentukan moral (akhlak) yang tinggi, karena pendidikan moral merupakan jiwa pendidikan Islam tanpa mengabaikan pendidikan jasmani, akal, dan ilmu praktis. Lihat $\mathrm{M}$. Athiyah al-Abrasyi. 2003. Prinsip-prinsip Dasar Pendidikan Islam, (Bandung: Pustaka Setia), hal. 13. Menurut Majid Zaki, pendidikan akhlak ini tidak tercermin pada masa jahiliyah, sehingga Rasulullah diutus kepada mereka untuk menyempurnakan akhlak. Sebagaimana dijelaskan dalam hadis "sesungguhnya aku diutus untuk menyempurnakan akhlak". Lihat Majid Zaki al-Jalad. 2004. Tadris al-Tarbiyah al-Islamiyah, al-Asas al-Nadzriyyah wa al-asalib al-'amaliyah, (Aman: Dar al-Massira), hal. 30

${ }^{4}$ Furqan Hidayatullah, Pendidikan Karakter: Membangun Peradaban Bangsa, (Surakarta: UNS Press, 2010), hal. 10-13 
96. Jikalau Sekiranya penduduk negeri-negeri beriman dan bertakwa, pastilah Kami akan melimpahkan kepada mereka berkah dari langit dan bumi, tetapi mereka mendustakan (ayat-ayat Kami) itu, Maka Kami siksa mereka disebabkan perbuatannya.

Lantas bagaimana cara yang bisa ditempuh untuk membangun karakter tersebut, tentu itu bukan persoalan yang mudah. Dalam kajian teorinya, ini bisa dilihat dari perdebatan di antara para ilmuwan, seperti Plato, Aristoteles, dan Kant. Plato berpikir bahwa orang yang terlepas dari nilai moral kepekaan rasa-perlu sampai pada definisi kebaikan yang benar-benar disarikan atau terlepas dari dasar afektif nonrasional dari banyak motivasi alamiah manusia. Pandangan Plato tersebut sejalan dengan Kant, bahwa jalannya penalaran sajalah yang berfungsi menentukan apa yang akan dianggap sebagai prinsip moral yang sah atau pertimbangan moral yang shahih. Akan tetapi, ada satu perbedaan yang signifikan antara Kant dan Plato. Kant percaya bahwa kondisi afektif jiwa seseorang yang pada dasarnya bersifat subyektif tidak terkait dengan status seseorang sebagai agen moral, sementara Plato tidak. Ia tampak lebih dekat dengan konsepsi karakter moral rasionalis "atas-bawah" yang sama sebagaimana kognitivis moral lainnya. ${ }^{5}$

Aristoteles setuju dengan Plato bahwa pencapaian kebajikan membutuhkan kebijaksanaan dan pemikiran rasional. lebih lanjut keduanya berpendapat bahwa tidak mungkin ada kebijakan tanpa kepekaan yang didasarkan rasa, tetapi juga tidak bisa ada pemikiran atau kebijaksaan moral.

${ }^{5}$ Larry P. Nucci dan Darcia Narvaez, Handbook Pendidikan moral dan karakter terj. Imam Baehaqie dan Derta Sri Widowatie, (Bandung: Nusa Media, 2014), hal. 152 
Itu artinya bahwa, kebajikan merupakan bentuk pertimbangan yang berhubungan dengan pengaturan secara rasional atau wajar akan nafsu dan emosi.

Sejalan dengan teori Plato dan Aristoteles, Kevin Ryan dan Thomas Lickona (1987) menyediakan model yang menarik mengenai perkembangan karakter yang melibatkan tiga unsur, yaitu pengetahuan, perasaan, dan tindakan. Untuk itu Lickona (1991) mengembangkan lebih lanjut model tersebut. Pertama, mahasiswa mempelajari muatan moral (moral knowing), belajar mengetahui yang baik melalui melalui informasi pembuatan keputusan rasional. penalaran moral, pengambilan keputusan, dan kemampuan untuk mendapatkan pengetahuan-diri melalui pengamatan dan evaluasi perilaku semuanya penting dalam dimensi perkembangan karakter ini. Kedua, domain afektif yang mencakup perasaan, simpati, kepedulian, dan cinta pada orang lain (moral feeling). Pada tahun 1992 Lickona menambahkan elemen ini dengan hati nurani, cinta, empati, dan kerendahan hati sebagai aspek penting darinya. Ada atau tidak adanya unsur perasaan dalam perkembangan karakter sangat menentukan apakah mahasiswa melakukan yang benar atau tidak. Oleh karena itu, domain afektif oleh Lickona dianggap sebagai jembatan penting dalam tindakan moral. Ketiga, tindakan tergantung pada kemauan, kompetensi, dan kebiasaan seseorang (moral action). Kehendak di sini berarti bahwa mahasiswa harus menghendaki cara mereka untuk mengatasi kepentingan diri sendiri, dan setiap kebanggaan atau kecemasan yang mereka miliki untuk melakukan apa yang mereka tahu adalah tindakan yang benar. Lebih lanjut, mahasiswa harus mengembangkan kompetensi untuk melakukan "yang baik" yang melibatkan ketrampilan tertentu 
dan mereka harus bebas memilih untuk mengulangi tindakan yang baik ini sebagai bentuk kebiasaan. ${ }^{6}$

Jika dipahami lebih lanjut, sebenarnya karakter itu bergerak dari kesadaran (awareness), pemahaman (understanding), kepedulian (concern), dan komitmen (commitment), menuju tindakan (doing atau acting). Untuk itu, perlu adanya kerjasama dan komitmen dari seluruh unsur yang ada di perguruan tinggi. Dalam implementasinya, membangun karakter sebaiknya diajarkan melalui tindakan, bukan hanya teoritis. Moral understanding sebagai aspek pertama yang harus diperhatikan dalam pendidikan karakter memiliki enam unsur, yaitu kesadaran moral, (moral awarness), pengetahuan tentang nilai-nilai moral (knowing about moral values), penentuan sudut pandang (perspective taking), logika moral (moral reasoning), keberanian mengambil keputusan (decision making), dan pengenalan diri (self knowledge). Unsur tersebut merupakan komponen-komponen yang harus ditekankan dalam pendidikan karakter, serta diajarkan kepada peserta didik dan diintegrasikan dalam seluruh pembelajaran secara kaffah.

Moral loving/moral feeling merupakan penguatan aspek emosi peserta didik untuk menjadi manusia berkarakter. Penguatan ini berkaitan dengan bentuk-bentuk sikap yang harus dirasakan oleh peserta didik, yaitu kesadaran akan jati diri, percaya diri (self-discipline), kepekaan terhadap penderitaan orang lain (emphaty), cinta kebenaran (loving the good), pengendalian diri (self-control), dan kerendahan hati

${ }^{6}$ Larry P. Nucci dan Darcia Narvaez, Handbook Pendidikan moral dan karakter terj. Imam Baehaqie dan Derta Sri Widowatie, (Bandung: Nusa Media, 2014), hal. 136 
(humility). Jika kedua aspek di atas terwujud, maka moral acting sebagai outcome akan dengan mudah dilakukan. ${ }^{7}$

Akan tetapi, dalam realitasnya, seringkali terjadi keterputusan di antara unsur-unsur tersebut, seringkali hanya sekedar moral knowing kemudian dituntut untuk bisa langsung moral action, tanpa moral feeling, sehingga wajar kalau karakter itu tidak terbangun. Hal ini bisa dilihat dari kasus-kasus yang terjadi dalam pendidikan kita.

Beberapa tahun terakhir ini, perguruan tinggi dikejutkan dengan beberapa penyimpangan yang dilakukan oleh mahasiswa maupun dosen. Banyaknya fenomena menyontek, ${ }^{8}$ kecanduan narkotika, ${ }^{9}$ hilangnya rasa malu, dan berkembangnya plagiarisme. Di sebuah perguruan tinggi ternama terungkap bahwa disertasi seorang promovendus mencontek skripsi hasil karya mahasiswa bimbingannya. ${ }^{10}$ Ironisnya, ada sejumlah guru besar yang juga melakukan plagiarisme. Sementara itu, ditemukan juga ada dosen di perguruan tinggi tertentu yang dapat dengan mudah memberikan nilai A jika mahasiswa yang akan ujian semester mau membayar sejumlah uang. ${ }^{11}$ Kondisi inilah yang hal. 14-15

7 Mulyasa, Manajemen Pendidikan Karakter, (Jakarta: Bumi Aksara, 2012),

${ }^{8}$ Ini menunjukkan tidak adanya karakter jujur dan mementingkan hasil daripada proses sehingga terabaikannya karakter jujur dan taat pada aturan Muhdar HM, Pendidikan Karakter menuju SDM Paripurna, dalam Jurnal Al-Ulum Volume. 13 Nomor 1, Juni 2013, Hlm 103-128

${ }^{9}$ Badan Narkotika Nasional (2011) menyatakan ada 3,6 juta pecandu narkoba di Indonesia khususnya kalangan muda. Nasir, "Pengembangan Pendidikan karakter berbasis budaya lokal di SMP Negeri 2 Kendari, tesis, Universitas Muhammadiyah Surakarta, 2013.

${ }^{10}$ Dalam Nasir, "Pengembangan Pendidikan karakter berbasis budaya lokal di SMP Negeri 2 Kendari, tesis, Universitas Muhammadiyah Surakarta, 2013.

${ }^{11}$ Muchlas Samani dan Hariyanto, Konsep dan Model Pendidikan Karakter, (Bandung: Remaja Rosdakarya, 2013), hlm. 5 
menjadikan pengembangan karakter bagi mahasiswa mendesak dilaksanakan di perguruan tinggi. ${ }^{12}$

Kasus yang hampir sama juga terjadi di Universitas Brawijaya dan Universitas Negeri Malang. Dari observasi dan wawancara awal, ditemukan bahwa seluruh isi makalah mahasiswa hasil dari copy paste internet, pakaian mahasiswi yang tidak sopan, tidak menghormati dosen, tutur katanya yang tidak sopan, mengabaikan dosen. Untuk itu, nilai karakter yang dikembangkan adalah karakter Islami. Pemilihan nilai ini disesuaikan dengan situasi dan kondisi serta masalah yang sering terjadi di perguruan tinggi tersebut sehingga dapat diidentifkasi nilai yang sangat dibutuhkan.

Pengembangan karakter Islami, memiliki keunikan dan perbedan dengan pengembangan karakter di dunia Barat. Perbedaan tersebut mencakup penekenanan terhadap prinsipprinsip agama yang abadi, aturan dan hukum dalam memperkuat moralitas, pemahaman tentang kebenaran, penekanan pahala di akhirat. Dengan kata lain, inti perbedaan tersebut terletak pada keberadaan wahyu ilahi sebagai sumber dan rambu-rambu pendidikan karakter dalam Islam. ${ }^{13}$

Berkaitan dengan pengembangan karakter Islami tersebut, ada beberapa ilmuwan muslim yang sudah mengembangkannya, seperti al-Ghazali, Ibnu Miskawaih, dan Ibnu Qayyim al-Jauziyah. Pada prinsipnya, ide-ide mereka tentang pengembangan karakter Islami tidak bisa dilepaskan

${ }^{12}$ Tulisan Buhari Luneto yang berjudul pendidikan karakter berbasis IQ, EQ, dan SQ dalam http://journal.iaingorontalo.ac.id/index.php/ir menjelaskan bagaimana problem kemerosotan moral bangsa yang mendesak diterapkannya pendidikan karakter dan tulisan Sri Wahyuni Tanshzil yang berjudul "Model Pembinaan Pendidikan Karakter pada lingkungan Pondok Pesantren dalam membangun kemandirian dan disiplin santri (Sebuah kajian pengembangan Pendidikan Kewarganegaraan)

13 Abdul Madjid, Pendidikan Karakter dalam Perspektif Islam, (Bandung: Remaja Rosdakaraya, 2011), hlm. 58 
dari pengalaman dan pengamalan ajaran agama Islam dalam kehidupan sehari-hari. Dengan kata lain, pengembangan karakter Islami berlandaskan ajaran Islam yang bersumber dari al-Quran dan Hadis.

Menurut al-Ghazali, akhlak itu harus menetap dalam jiwa seseorang dan perbuatan itu muncul dengan mudah tanpa memerlukan pemikiran, pertimbangan, atau penelitian terlebih dahulu. ${ }^{14}$ Lebih lanjut dia mengatakan bahwa berakhlak mulia itu menghilangkan semua adat kebiasaan tercela yang sudah digariskan dalam agama Islam serta menjauhkan diri dari perbuatan tercela tersebut, kemudian membiasakan adat kebiasaan yang baik, melakukannya dan mencintainya. ${ }^{15}$

Hal senada juga diungkapkan oleh Ibnu Miskawaih yang menyatakan bahwa akhlak adalah keadaan jiwa yang menyebabkan seseorang bertindak tanpa dipikirkan terlebih dahulu. la tidak bersifat rasional, atau dorongan nafsu. ${ }^{16} \mathrm{Ibn}$ miskawaih menambahkan bahwa tidak ada materi yang spesfik untuk mengajarkan akhlak, tetapi dapat diimplementasikan ke dalam banyak ilmu di mana tujuan utamanya adalah sebagai pengabdian kepada Tuhan. ${ }^{17}$

Sedangkan menurut Ibnu Qayyim al-Jauziyah, pendidikan karakter secara spesifik mengarah kepada pembentukan akhlak, kepribadian, etika, dan prilaku yang erat kaitannya dengan jiwa seseorang. Mengetahui jiwa merupakan jalan yang lurus untuk mendapatkan akhlak yang

14 Enok Rohayati, Pemikiran al-Ghazali tentang Pendidikan Akhlak, Jurnal Ta'dib, Vol. XVI, No. 01, Edisi Juni 2011, hlm. 105

15 Zubaedi, Desain Pendidikan Karakter: Konsepsi dan Aplikasinya dalam lembaga Pendidikan, (Jakarta: Kencana, 2012), hlm. 184

16 Ibid., hlm. 105

${ }^{17}$ Nur Ainiyah, Pembentukan Karakter melalui Pendidikan Agama Islam, Jurnal Al-Ulum

Volume. 13 Nomor 1, Juni 2013, hlm.32 
mulia. Oleh karena itu, setiap individu harus mengetahui sesuatu yang dapat membersihkan jiwanya supaya beruntung dan sesuatu yang dapat mengotorinya sehingga merugi.

Pengembangan karakter Islami tersimpul dalam karakter pribadi Rasulullah. ${ }^{18}$ Dalam pribadi Rasulullah bersemai nilai-nilai akhlak yang mulia dan agung, yaitu shidiq,amanah, fathanah, dan tabligh. ${ }^{19}$ Shidiq adalah sebuah kenyataan yang benar yang tercermin dalam perkataan, perbuatan atau tindakan, dan keadaan batinnya. ${ }^{20}$ Amanah adalah sebuah kepercayaan yang harus diemban dalam mewujudkan sesuatu yang dilakukan dengan penuh komitmen kompeten, kerja keras, dan konsisten. Fathanah adalah sebuah kecerdasan, kemahiran, atau penguasaan bidang tertentu yang mencakup kecerdasan intelektual, emosional, dan spiritual. ${ }^{21}$ Tabligh adalah sebuah upaya merealisasikan pesan atau misis tertentu yang dilakukan dengan pendekatan atau metode tertentu. ${ }^{22}$

\section{B. Urgensi Kajian Karakter Ulul Albab dalam al-Quran}

Al-Quran adalah kalam Allah yang diturunkan sebagai petunjuk manusia. ${ }^{23}$ Oleh karena itu, maka tidaklah aneh jika al-Quran dapat memenuhi semua tuntutan kemanusiaan berdasarkan asas-asas pertama konsep agama samawi. ${ }^{24}$ Dengan segala misteri dan kelebihannya, al-Quran menyimpan potensi yang begitu dahsyat. Sejarah mencatat

${ }^{18}$ Madjid, Pendidikan Karakter..., hlm. 59

${ }^{19}$ Rakhmawati, Pendidikan Karakter dalam Perspektif Islam,Jurnal Al-Ulum Volume. 13 Nomor 1, Juni 2013, hlm.203

${ }^{20}$ Furqan Hidayatullah, Pendidikan Karakter..., hlm. 61

${ }^{21}$ Ibid., hlm. 62

22 Ibid., hlm. 63

${ }^{23}$ Q.S. al-A'raf ayat 158, QS. Al-Furqan ayat 1, Q.S. al-Ahzab ayat 40

24 Manna' Khalil al-Qattan, Studi ilmu-ilmu al-Quran terj. Mudzakir, (Bogor: Pustaka Lentera Antar Nusa, 2009), 11-12 
pengaruh besarnya ketika ia melahirkan sebuah peradaban yang oleh Nasr Hamid Abu Zaid diklaim sebagai "peradaban teks" (hadharah al-Nass). ${ }^{25}$

Dalam terminologi kajian ilmu al-Quran, sebagaimana yang ada dalam beberapa ayat al-Quran ${ }^{26}$, kehadiran alQuran mempunyai beberapa fungsi. Fungsi yang paling ideal adalah dari beberapa fungsi yang lain adalah al-Quran menjadi petunjuk 27 sebagaimana tergambar dalam ayat berikut yang artinya: "Quran ini memberi petunjuk kepada jalan yang lebih lurus (Q.S. al-Isra' [17]: 9). Dalam fungsinya sebagai petunjuk, maka ia membentuk manusia pada konstruksi idealnya sebagaimana yang dikehendaki Tuhan melalui ayatayat yang ada. ${ }^{28}$

Kehadiran teks al-Qur'an di tengah umat Islam telah melahirkan pusat pusaran wacana keislaman yang tidak pernah berhenti dan menjadi pusat inspirasi bagi manusia untuk melakukan penafsiran dan pengembangan makna atas

${ }^{25}$ Menurut Nasr, hal ini tidak berarti bahwa ttekslah yang membangun peradaban. Sebab, teks apapun tidak dapat membangun dan menegakkan ilmu pengetahuan serta peradaban. Yang membangun dan menegakkan peradaban adalah dialektika manusia dengan realitas di satu pihak, dan dialognya dengan teks di pihak lain.

${ }^{26}$ Kandungan ayat-ayat al-Quran mencakup banyak aspek kehidupan manusia, termasuk konsep ketuhanan (tauhid) juga. Banyak al-Quran yang menjelaskan secara khusus tentang Tuhyan. Penjelasan lebih lanjut dapat dilihat dalam Mohammad Abu Hamdiyyah. The Quran: an Introduction. (LondonNewyork: Roudledge, 2000), 50. Dalam kaitannya dengan ulul albab maka penting sekali untuk memahami konsep tersebut sebagai dasar (pedoman) dalam berperilaku.

${ }^{27}$ Kementerian Agama RI. Tafsir al-Quran Tematik, Kedudukan dan Peran Perempuan (Jakarta: Lajnah Pentashihan Mushaf al-Quran Badan Litbang dan Diklat Kementerian Agama RI), xix

${ }^{28}$ Hal ini dikarenakan memang al-Quran sejak semula diturunkan oleh Allah untuk merombak budaya zaman kegelapan (jahiliyah) menuju zaman yang terang dengan konsep keyakinan atau keimanannya. Maka sudah menjadi kewajiban bagi umat Islam yang ingin mendapatkan petunjuk hidup untuk berpedoman pada al-Quran. Lihat M.A. Draz. Introduction to the Quran, (LondonNewyork: I.B. Touris Publisher), $x$ 
ayat-ayatnya. Bahkan al-Quran juga menjadi bahan kajian bagi sarjana-sarjana Barat. ${ }^{29}$ Dalam hal ini, al-Quran dapat diposisikan sebagai mitra dialog bagi para pembacanya. Perspektif ini mengasumsikan bahwa teks al-Quran merupakan sosok pribadi yang mandiri, otonom, dan secara obyektif memiliki kebenaran yang dapat dipahami secara rasional. ${ }^{30}$

Akan tetapi, yang perlu diperhatikan bahwa al-Quran tidak boleh ditafsirkan hanya dengan akal saja tanpa landasan yang kuat dan haq, meskipun sifatnya progressif. ${ }^{31}$ Maksudnya, bahwa orang yang menafsirkan dengan terlintas keraguan dan dugaan yang todak dapat dipertanggung jawabkan tanpa mengambil daili, maka tindakan tersebut tidak diperbolehkan. ${ }^{32}$ Sebagaimana disebutkan dalam surat al-isra' ayat 36:

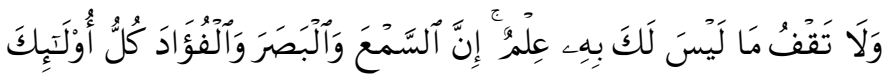

$$
\text { كَانَ عَنْهُ مَسْعُولاًا }
$$

36. dan janganlah kamu mengikuti apa yang kamu tidak mempunyai pengetahuan tentangnya. Sesungguhnya pendengaran, penglihatan dan hati, semuanya itu akan diminta pertanggungan jawabnya. (Q.S. al-Isra' [17]: 36)

${ }^{29}$ Nicolai Sinai. The Quran As Process dalam Angelika Neuwirth, Nicolai Sinai, Michael Maex. (ed), The Quran in Context, Historical and Literary Investigations into the Quranic Milieu (Leiden-Boston: Brill), 407

30 Muhammad Shahrur, Prinsip dan Dasar Hermeneutika al-Quran Kontemporer terj. Sahiron Syamsudin dan Burhanuddin Dzikri, (Yogyakarta: elSAQ Press, 2004), xv-xvi

${ }^{31}$ Edip Yuksel, Layth Saleh al-Shaiban, Martha Schulte-Nafeh, al-Quran A. Reformist Translation, (United States of America: Brainbow Press, 2007), 10

32 Sayyid Muhammad Alwi al-Maliki, Keistimewaan-keistemewaan al-Quran terj. Nur Faizin, (Yogyakarta: Mitra Pustaka, 2001), 216-218 
Sesuatu yang sangat agung dari petunjuk al-Quran, berkenaan dengan visi pemikiran dan ilmu pengetahuan adalah bahwa al-Quran memberi penghargaan terhadap ulul albab dan kaum cendikiawan, atau kaum intelektual. Allah memuji mereka dalam banyak ayat dalam surat-surat Makkiyah dan Madaniyah. Al-Quran mengekspos keluhuran orang yang beriman dan berilmu sebagai hamba-hamba Allah yang memiliki kedudukan tinggi. Bahkan, mereka yang memiliki kedudukan dan mendayagunakan anugrah Allah (potensi akal, kalbu, dan nafsu) diberi gelar khusus dengan sebuah panggilan ulul albab. Ulul albab akan senantiasa mempergunakan akalnya untuk berfikir tentang segala ciptaan Allah dan tunduk atas segala ketentuannya. Mereka akan sellau mengadakan perbaikan dan penyelidikan terhadap fenomena yang ada karena keistimewaan yang telah diberikan Allah kepadanya.

Kelompok ulul albab bukan saja sudah semakin langka di dunia pada umumnya, tetapi juga langka di dunia Islam. Yang banyak adalah manusia-manusia yang hanya berfikir singkat dan terbatas oleh kesibukan hidup dari hari ke hari. Pada beberapa ayat, ia selain dibekali dengan beberapa karakter yang ideal, ia juga mengakomodasi karakter dari tipe-tipe manusia lain yang disebutkan di dalam al-Quran. Misalnya, ulin nuha yang berarti orang yang mempunyai akal, atau ulil al-absar (orang yang mempunyai orientasi ke depan). Orang-orang mempunyai cakrawala pemikiran yang dalam dan pandangan jauh ke depan sebagaimana yang disebutkan dengan istilah di atas sebenarnya dapat dikategorikan ulul albab.

Oleh karena itu penting kiranya untuk meneliti secara komprehensif bagaimana sesungguhnya kontruksi ulul albab dalam al-Qur'an yang dikaitkan dengan tipe ideal manusia. 
Hal ini dimaksudkan agar mampu memprofokasi gerakan revolusi mental sebagai langkah awal rekayasa sosial untuk membentuk komunitas sosial yang ideal yang terkonstruks dari pribadi-pribadi yang ideal pula.

Secara etimologis, kata albab adalah bentuk plural dari kata $l u b b$, yang berarti saripati sesuatu. Kacang misalnya, memiliki kulit yang menutupi isinya. Isi kacang disebut $l u b b$. Berdasarkan definisi etimologi ini, dapat diambil pengertian terminologi bahwa ulul albab adalah orang yang memiliki akal yang murni, yang tidak diselubungi oleh kulit, yakni kabut ide yang dapat melahirkan kerancuan dalam berfikir. 33 Singkatnya, secara harfiah, ulul albab adalah orang yang berakal. Dalam pengertian yang lebih jauh, ulul albab bukan hanya memiliki kekuatan daya piker dan daya nalar, melainkan juga daya zikir dan spiritual. Kedua daya yang dimilikinya akan digunakan secara optimal dan saling melengkapi sehingga mengantarkan pada keseimbangan antara kekuatan penguasaannya terhadap ilmu pengetahuan (sains) dan penguasaannya terhadap ajaran-ajaran agamanya dan spiritualitas. ${ }^{34}$

Agak sedikit berbeda, Saefuddin mengemukakan bahwa ulul albab adalah intelektual muslim atau pemikir yang memiliki ketajaman analisis atas fenomena dan proses alamiah, dan menjadikan kemampuan tersebut untuk membangun dan menciptakan kemaslahatan bagi kehidupan manusia. $^{35}$ hlm. 394

${ }^{33}$ M. Quraish Shihab. 2006. Tafsir al-Misbah jilid 1, (Jakarta: Lentera hati),

34 Abuddin Nata. 2009. Ilmu pendidikan Islam dengan pendekatan multidislipiner, (Jakarta: Raja Grafindo Persada), hal. 69

${ }^{35}$ AM Saefuddin, AM. 1987, Desekulerisasi Pemikiran Landasan Islamisasi, (Bandung: Mizan), hal. 34 
Istilah ulul albab dapat ditemukan dalam teks al-Qur'an sebanyak 16 kali ${ }^{36}$ di beberapa tempat dan topik yang berbeda, diantaranya dalam Q.S: Al- Baqarah; 179, 197, 269; Al- Imran: 7, 190; Al-Maidah: 100; Yusuf: 111, Al-Ra'd: 19-24, Ibrahim: 52; Shaad: 29, 43; Al-Zumar: 9, 18,21; Al-Mu'min: 54,dan Al-Thalaq:10. ${ }^{37}$ Dalam hal ini penulis akan membahas 16 ayat tersebut dengan membatasi pada penafsiran Wahbah al-Zuhaily dalam tafsir al-Munir dan M. Quraish Shihab dalam Tafsir al-Misbah. Hal ini didasarkan pada ketertarikan penulis terhadap kedua mufassir yang sangat berpengaruh dalam dunia Islam, khususnya pada abad ke-20.

Wahbah al-Zuhaliy dilahirkan di desa Dir Athiyah, daerah Qalmun, Damsyiq, Syria pada 6 maret 1932 M/1351H. Ia dikenal alim dalam bidang fiqih, tafsir dan Dirasah Islamiyyah. Ia menulis buku dan artikel dalam berbagai ilmu Islam. Buku-bukunya melebihi 133 buah dan risalah-risalah kecil lebih dari 500 makalah. Satu usaha yang jarang dapat dilakukan oleh ulama kini seolah-olah ia merupakan al-Suyuti kedua (al-Suyuti al-Thani) pada zaman ini. Di antara kitabkitabnya adalah Tafsir al-Munir fi al-Aqidah wa al-Syari'at wa alManhaj yang terdiri dari 16 jilid yang diterbitkan oleh Dar alFikr Damsyiq pada tahun 1991. Kitab inilah yang akan menjadi salah satu dari fokus penelitian ini yang lebih menitikberatkan pada penafsiran ulul albab dalam kitab tersebut. Hal ini didasarkan pada karakteristik yang ada dalam kitab tersebut, di mana cara penafsiran ayatnya begitu komprehensif dengan kajian mufradat, balaghah, asbab al-nuzul, tafsir, dan yang tidak kalah pentingnya adalah figh al-hayat sehingga penafsirannya cocok untuk konteks saat ini.

\footnotetext{
${ }^{36}$ Raghib al-Asfahani. 2004. Mu'jam mufradat alfaz al-Quran. (Beirut: Dar alKutub al-ilmiyah), hal. 500

37 Khudhori Sholeh, dkk. 2008. Tarbiyah Ulul Albab, Peneguhan Jatidiri,Membangun Peradaban Islam, (Malang: UIN Malang Press), hal. 53
} 
Sedangkan M. Quraish Shihab adalah seorang ahli tafsir yang juga pendidik, cendikiawan Muslim dalam ilmu-ilmu alQuran. Keahliannya dalam bidang tafsir diabadikan dalam bidang pendidikan. Selain kedudukannya sebagai Pembantu Rektor, Menteri Agama, ketua MUI, Staf Ahli Menteri Pendidikan dan Kebudayaan, Anggota badan Pertimbangan Pendidikan, ia juga rajin menulis karya ilmiah, dan ceramah yang erat kaitannya dengan kegiatan pendidikan. Dengan kata lain, ia adalah seorang ulama' yang memanfaatkan keahliannya untuk mendidik umat melalui sikap dan kepribadiannya yang patut diteladani. Penampilannya yang sederhana, tawadhu, sayang kepada semua orang, jujur, amanah, dan tegas dalam prinsip adalah merupakan bagian dari sikap yang seharusnya dimiliki oleh seorang guru. ${ }^{38}$

Keunggulan itulah yang menjadikan peneliti tertarik untuk mencoba mengkaji dan melihat lebih dalam tentang Wahbah al-Zuhaily dan M. Quraish Shihab, dua mufassir kontemporer yang telah mewarnai corak penafsiran al-Quran, khususnya tentang ulul albab yang dikaitkan dengan tipe manusia ideal yang dijelaskan Allah dalam al-Quran.

${ }^{38}$ M. Quraish Shihab, Tafsir al-Misbah: Pesan, kesan dan keserasian al-Quran, (Jakarta: Lentera Hati, 2002), ii 